\title{
CEREBRAL CORTICAL GENE EXPRESSION IN ANEMIC RATS: MICRO- ARRAY ANALYSIS
}

Françoise Briet PhD, C David Mazer MD, Andrew J Baker MD, Gregory MT Hare MD

$\mathrm{PhD}$. University of Toronto, St. Michael's Hospital, 30 Bond Street, Toronto, Ontario

M5B 1W8.

INTRODUCTION: Increased mortality and neurological morbidity occur in acutely anemic patients. However, mechanisms of anemia induced organ injury have not been defined. We hypothesize that assessment of cerebral cortical gene ex pession will identify potential mechanisms of neurological injury in acutely anemic rats.

METHODS: With Animal Care Committee approval, anesthetized rats (2\% isoflurane) were hemodiluted with pentastarch and then recovered for $6 \mathrm{~h}$ and $24 \mathrm{~h}$. Negative controls were not hemodiluted. Positive hypox $\dot{\boldsymbol{c}}$ controls were ex poed to $10 \%$ ox ygen $(\mathrm{n}=6$ rats/group/time). At $6 \mathrm{~h}$ or $24 \mathrm{~h}$, cerebral cortex was harvested, snap frozen and total RNA ex racted. Microarray analysis was performed at a microarray facility. Five $\mu \mathrm{g}$ of total RNA from two rats was used to prepare cRNA to be assessed on one microarray (Affymetrix GeneChip Rat 230_2) Data from anemic and hypox i rats were compared to data from negative controls. Data analysis was performed using GeneSpring Software (Silicon Genetics). Genes showing a $50 \%$ or greater change were assessed by ANOVA (p $<0.05$ defined as significant).

RESULTS: The average hemoglobin concentration after hemodilution was $57 \pm 16 \mathrm{gL}^{-1}$. After $6 \mathrm{~h}$ and $24 \mathrm{~h}$ of anemia, 396 and 51 genes changed significantly, respectively. Hypoxic genes: Vascular endothelial growth factor (VEGF) increased 1.5 fold (24h, $\mathrm{p}<0.02)$ while caspase 9 increased over 2.0 fold $(6$ and $24 \mathrm{~h}, \mathrm{p}<0.002)$, in anemic rats. Both genes also increased in hypox $\dot{c}$ rats. Nitric oxide synthase (NOS) genes: No increases in NOS genes were detected in anemic rats. Methallothionein, an important intracellular mediator of nitric ox de signaling, increased 14 fold in anemic and hypox $\dot{\mathbf{c}}$ rats $(6 \mathrm{~h}, \mathrm{p}<0.0004)$. Inflammatory genes: Intercellular adhesion molecule 1 (ICAM 1) increased 13 fold $(6 \mathrm{~h}, \mathrm{p}<0.005)$, small inducible cytokine A2 increased 17 fold $(24 \mathrm{~h}$, $\mathrm{p}<0.006)$, chemokine ligand 10 increased 40 fold $(6 \mathrm{~h}, \mathrm{p}<0.007)$ and interleukin 6 (IL-6) increased 4 fold $(6 \mathrm{~h}, \mathrm{p}<0.002)$. None of these increases occurred in hypox $\dot{\mathbf{c}}$ rats.

CONCLUSIONS: Acute anemia resulted in significant changes in cerebral cortical gene ex pession. Increased ex pession of VEGF, caspase 9 and methallothionein may reflect a hypox $\dot{\mathbf{c}}$ cellular response. Conversely, anemia activated many inflammatory gene, which did not change in hypox $\dot{\mathbf{c}}$ rats, suggesting that inflammation may pose an additional mechanism of cerebral injury during anemia. (CAS, PSI AIRE support). 